\title{
The role of women in political participation in work to achieve development in local societies
}

Shadia Rabie Zaky (PhD)

Associate Professor of Community Organization Higher Institute of Social Work in Cairo Moustafa Mohamed Moawad (PhD) Assistant Professor of Community Organization Higher Institute of Social Work in Cairo 
The Egyptian Journal of Social Work (EJSW) https://ejsw.journals.ekb.eg/e ISSN: 2356-9204 Vol 11, Issue.1, January2021 


\section{The Egyptian Journal of Social Work (EJSW) https://ejsw.journals.ekb.eg/e}

ISSN: 2356-9204

Vol 11, Issue.1, January2021

Abstract:

This is a descriptive study aimed at identifying the role of women, as members of councils of human rights organizations, in the development of the local community. The study uses a social survey method of two different segments: first, a sample consisting of female members of the boards of directors of organizations within the study community, totaling (17) individuals, second, a random sample of the beneficiaries of the services of those organizations, totaling (215) individuals. The study used the following data collection tools: a questionnaire completed by the female members of the organizations' councils, and an interview with the beneficiaries of the organizations' services in the local community. The results of the study showed that the most important aspect of the role of women_in the development of the local community was their participation in the formulation of policies by the authorities responsible for community development. The results of the study hypotheses also confirmed that there were no significant differences $(0.05 \geq \alpha)$ in the roles of political participation that women play in developing the local community, from the point of view of community members and female board members of organizations according to variables of (educational qualification, profession, age).

Keywords:The role - Political Participation -women- development -Local Societies

Introduction:

There is no doubt that the role of women is of great importance in social, economic and political development. A woman has the same energies and abilities as a man, and a woman who understands the power of her role and duties, and is keen to exercise her political rights, will have a profound impact on the development of her society, driving her to achieve development, progress and superiority. (Al-Darir \& Zakaria, 1997, p.99)

The economic, political and social transformations at the end of the last century and the beginning of this century, led to radical changes in our contemporary world. Whether in terms of economic blocs, political alliances, or the reality of cultural and ideological conflict, these transformations have created a new reality related to the developmental roles of women within their community. (Al-Srouji, 2012, p.393)

Over the past few decades, the world has witnessed the growth of international interest in women's issues where women's movements have struggled for equality with men. (Pelak, C.F., Taylor, V., Whittier, N., 1999, pp.147-148)The sixties, seventies and eighties of the last century witnessed the emergence of regional and international women's work networks. (Miles, A.,_1996, p.57) 


\section{The Egyptian Journal of Social Work (EJSW) https://ejsw.journals.ekb.eg/e}

ISSN: 2356-9204

Vol 11, Issue.1, January2021

Consequently, international interest in women's issues and the need for women to participate and integrate into various areas of life to achieve equality and development has arisen. Thus, the first international conference for women was held in Mexico in the year (1975), followed by the second world conference for women in (1980), held in Copenhagen, and the third in (1985), in Nairobi. The most prominent of these conferences was the Fourth International Conference on Women held in (1995) in Beijing, where some important development concepts related to women emerged, aiming to enhance the image women have of themselves, their confidence in their capabilities, and their great value in the home and society. (Mason, D. 2006, p.18)

The United Nations has had a major role in protecting women's rights, including their participation and social integration, leading to the implementation of the Security Council Resolution 1325 on women, peace and security which was adopted on October 31, 2000. (Security Council, 2000) This decision was considered a dividing line for the development of women's rights, as it is the first official and legal document issued by the Security Council requesting respect for the rights of women and support for their participation in peace negotiations and the reconstruction that comes after conflict. (Anwarul, Chowdhury, 2010)

The importance of participation may be attributed to helping control and govern the future plans of society, identifying new global developments, and helping to find cooperation between planning and development in new services provided to the community. (Ross, 1995, p.20)

By looking at studies and research that deal with women's participation, we find the study of Agbalajobi, (2010) which aims to identify the problems facing women in their pursuit of political involvement. The study determines the factors responsible for the low participation of women politically. Which was represented in Society is ruled by men And they control On women, And that men possess The power of supremacy, Where societal values assume that political activities are male.

The study of Jane \& Ganigera (2013) addressed strategies to enhance women's political involvement in India. The study concluded that without educating women and empowering women in all aspects of our social, economic and political life it is almost impossible for society to flourish. It identified that education is the basic condition to first empower women and the second is law reform, which makes laws gender-neutral.

The study of Kassa (2015) indicated the challenges and opportunities for women's political involvement in Ethiopia, emphasizing that economic, religious, social and cultural factors have contributed to the weak political participation of women in the country. Therefore, the participation of 


\begin{tabular}{||cr|}
\hline The Egyptian Journal of Social Work (EJSW) https://ejsw.journals.ekb.eg/e \\
ISSN: $2356-9204$ & Vol 11, Issue.1, January2021 \\
\hline
\end{tabular}

women on an equal footing with men in decision-making and politics is not only a demand for justice or democracy; rather, it is a necessary precondition to take into account the interests of women.

The study of Ghaplanyan \& Melikyan (2015) is about strengthening the political participation of women in the Republic of Armenia. The study found that the political representation of women is much less than the global goal of $30 \%$, and that there is strong resistance to women's involvement in political life due to the absence of a comprehensive national agenda to support women's issues. The study recommends supporting awareness-raising campaigns to recognize women's activities in political parties and civil society organizations.

The study of Muhammed, (2017) dealt with the political participation of women in local government in Ethiopia. The results of the study found that women occupy $50 \%$ of the seats in local councils in each of the local governments, and that $22.5 \%$ of workers in the executive bodies are women with $22 \%$ in the executive branch. This indicates that women are less represented, and that local governments lag behind in appointing women to prominent positions as local officials often do not trust the ability of women.

From this standpoint, the inclusion of women in development places them in a position of strength so that they become a partner to men in responsibilities and duties, and reflect the progress of society in various fields.

Several studies have emphasized the importance of the role that women play in achieving development within local communities. Mentioned in the study of ESCWA (2012) are the most important obstacles to women's participation in achieving the development of their societies. These include policies which neglect the role of women in development, and organizations and legislations that show bias towards women yet do not achieve their effective participation. A study by (Bradshaw., Castellino, \& Dipo,_(2013) confirmed the importance of the role of women in the development process, and emphasized the obstacles facing this role, including the lack of equality with men in their ability to influence, make and take decisions related to community development. The study of Kandy, (2017) aimed to reveal the importance of the woman's role in developing her environment, to achieve sustainability and development. The study emphasized that women are still suffering from exclusion from positions of leadership, and recommended the importance of training women and developing their capabilities, encouraging them to participate with decision makers in order to achieve the development of the society in which they live.

The subject of women's political involvement and its relationship to the development of local communities touches on a wide range of issues, which extend to various life issues. Studying the degree of women's 


\section{The Egyptian Journal of Social Work (EJSW) https://ejsw.journals.ekb.eg/e}

ISSN: 2356-9204

Vol 11, Issue.1, January2021

involvement is particularly important, where a high degree of social discrimination_is faced, because women experience some degree of inequality with men in terms of participation in political life. The role of women remains weak in other developmental fields due to factors including the dominance of a traditional male culture, which limits the achievement of full equality in the long run; the lack of NGO social development policies that would strengthen the role of women in the development of their local societies._(Saeed, 1998, p.96)

\section{Study problem:}

Undoubtedly, women play a major role in the development of their local societies, whether that role is at the various political, economic and social levels, or through what they possess.

Of energies and abilities that qualify her to play this role, the participation of women in the development process is a cornerstone and it is not necessarily less than the participation of a man, if it is not equal to him. Political involvement is a settled mechanism for improving the status of women and adjusting their position in society, which can be activated by civil society organizations such as parties, unions and human rights institutions. Political involvement represents the defense of the rights of different groups of society, and directs the efforts of the state to satisfy the needs of members of society in order to achieve development in these societies.

Through the abovementioned, it is clear that the participation of women in political work is one of the most important elements of the democratic process in society, and reflects the development and progress of society. Therefore, the weakness of democratic mechanisms in society contributes to marginalizing women's political involvement. The degree of community growth is also measured by its ability to integrate women into public and private society issues, and to enhance their capabilities to contribute towards the development process within it.

Hence, the current study sought to reveal the reality of women's in political involvement, as it tries to shed light on the most prominent obstacles that contribute to weakening women's participation politically and thus weakening their role in the process of achieving the development of their society. From here, the idea of the current study crystallized to answer the following main question: "What are the roles of political participation played by women to achieve development in local societies?"

Theoretical premises of the study:

Exchange Theory: The theory of exchange has found interest from social work practitioners because it focuses on understanding the functions of society and identifying the behavior of its members. Additionally, exchange theory takes appropriate measures to deal with individual problems on the basis that 


\begin{tabular}{||cr|}
\hline The Egyptian Journal of Social Work (EJSW) https://ejsw.journals.ekb.eg/e \\
ISSN: $2356-9204$ & Vol 11, Issue.1, January2021 \\
\hline
\end{tabular}

behavior is the main component in building a society and the organizations that operate within it. Therefore, reciprocal ties are created between individuals, imposed by the nature of the situation, and through these reciprocal processes social organizations are created to meet the needs of society. (Abrai \& Rosenthal, 2008, p.1481)

The basic assumptions of exchange theory.

1- Participating individuals engage in reciprocal relationships to achieve desired goals.

2- All social activities include a cost of (time - energy - resources).

3- Participants in the exchange process strive to ensure cost is lower than the return.

The exchange process begins with the social interaction, whether between individuals, groups or organizations, where one participant tries to gain some kind of benefit from another actor by exchanging things with them, and if the other participant feels they will also benefit from this exchange, it will happen. (Ahmed, 1999, p.12)

\section{The theory of exchange can be used as follows:}

This theory seeks to find a process of integration between the variables of the study represented in political involvement and the development of local communities, as it refers to the material aspects of exchange. It also refers to non-material things such as social centers, achieved by political participation, where some researchers believe that many exchanges take place without awareness or full awareness of them. Politicians who make promises to the masses in many countries of many social and economic reforms all expect something in return, however, in many cases this is not clear.

\section{Research Goals:}

The study seeks to achieve the following objectives:

a) Determine the roles of political participation that women play in developing their local community, as seen from the perspective of members of the local community.

b) Reveal the nature of differences in the roles of political participation that women play in the development of their local community, as seen from the perspective of members of society, which are attributed to the following variables (gender, educational qualification, profession, age).

c) Reveal the nature of differences in the roles of political participation women play in the development of their local community, as seen from the perspective of the woman herself, which are attributed to the following variables (educational qualification, profession, age, volunteer work in human rights organizations).

d) Identify the obstacles that limit women's political participation, through human rights organizations, in achieving the development of local 
communities.

e) Produce proposals to support women's political participation, through human rights organizations, in achieving community development.

Study hypotheses:

The objectives of the study are achieved by answering the following research hypotheses:

a) There are statistically significant differences, at the level of significance of $(0.05 \geq \alpha)$, between the roles of political participation that women play in the development of their local community, from the perspective of members of society, attributed to the following variables (gender, educational qualification, profession, age).

b) There are statistically significant differences, at the level of significance of $(0.05 \geq \alpha)$, between the roles of political participation that women play in the development of their local community, from the perspective of the woman herself, attributed to the following variables (educational qualification, profession, age,).

The concepts:

Role: "An organized pattern of norms with regard to the behavior of an individual with a particular function in the community." Or "The function of the individual in the community and the role played by the individual in a social group or position". (Zahran, 2000,_p.164)

Political Participation: "The process through which an individual plays a role in the political and social activity of their country, and which gives them an opportunity to contribute to setting the general goals of that community, and to suggest the best means to achieve and accomplish those goals". (AlDawwa, 2018: p15)

Political participation can also be defined as "the practice of politics on a public level." (Bystydzienski,_1991,_p.1)

Operational definition of political participation of women according to this study: "The general role that women play within society, through effective participation in formulating and taking decisions that affect public affairs, in addition to setting goals and public policies within society through their activities in human rights associations that have a major role in achieving the development of local communities. This enables women to engage in political participation, mainly on the basis of their social and political empowerment, with the aim of participating in the development and progress of their local societies".

Development: "A process of social change planned by a person to move society to a better position in accordance with his economic, social and intellectual needs and capabilities". (El-Gohary,_1998,_p.74) Or "Vital, mental, social and cultural changes that take place in the life cycle of every member of 
The Egyptian Journal of Social Work (EJSW) https://ejsw.journals.ekb.eg/e ISSN: 2356-9204

Vol 11, Issue.1, January2021

society, performed in a continuous, appropriate, coherent and consecutive manner in a predictive and plann way, but varying in rate from one individual to another". (Al-Sukari, 2000, p.247)

Local Societies: "Groups of the population whose lives are of a general cultural nature with common interests and goals, similar social values, and rules of custom, collective behavior and mutual services, giving them a sense of loyalty and belonging as part of a community". (Al-Sukari, 2000, p.101)

The concept of community development: "The efforts made by citizens to improve the conditions of their local communities, as well as increasing the capacity for self-participation and the integration of efforts in connection with local community affairs"._(Dunham,_1970,_p.140)

The operational definition of women's political participation in the development of their local societies: "'The set of roles that women play, Represented by: Proper planning of all programs and services provided to individuals in the local community ,Estimation of the needs of local community members and work to satisfy them, Determination of the priority of services provided to citizens within the local community, Participation in policy-making with the authorities responsible for local community development, and Work making optimal use of the organization's resources and capabilities to serve citizens within the local community, and through which they participate in political life, by making and taking decisions related to setting goals and public policies within society. These roles are exercised by human rights organizations that aim to protect the rights of vulnerable groups to ensure the development of their community".

Methodology:

This study belongs to the pattern of descriptive and analytical studies, with the aim of determining the role of women's political involvement in achieving the development of local communities. Additionally, the study aims to reveal the nature of the differences in the roles of political participation that women play in the development of their local community from the viewpoint of all members of society.

The current study uses the social survey methodology. It relied on a comprehensive inventory of female members of councils of human rights organizations that are concerned with the development of local communities in the study community. It also depended on a social survey of members of the community who benefit from the services of human rights organizations in developing their local community. 
The Egyptian Journal of Social Work (EJSW) https://ejsw.journals.ekb.eg/e

ISSN: 2356-9204

Vol 11, Issue.1, January2021

\section{Tools:}

\section{The study was based on two tools:}

1- A questionnaire regarding the roles of political participation played by women working on the development of local communities, which was applied to female members of the boards of directors of human rights organizations.

2- Structured interview with the beneficiaries of the services of these organizations to understand their opinion on the political work of women to develop their society.

\section{Design of the study questionnaire:}

The study relied on a questionnaire applied to female board members of human rights organizations, designed using the following steps:

1- Perusal of the tools of many other studies related to the subject of the questionnaire, including (Agbalajobi, 2010), (Jane \& Ganigera, 2013), (Jane \& Ganigera, 2013), (Kassa: 2015) (Ghaplanyan \& Melikyan, 2015) and (Muhammed, 2017).

2- Determining the questionnaire phrases and how they relate to the index measured. The questionnaire was divided into four indicators; a) primary data index, b) an indicator of the roles of political participation that women play in the development of their local community, c) an indicator of the obstacles that limit women's political involvement in human rights organizations to achieve the development of local communities, d) an indicator of the most important proposals to support women's political involvement in human rights organizations to achieve societal development.

3- Specifying the weights and paragraphs of the questionnaire: The questionnaire was constructed and divided into categories so that the results of the study could be reached using the arithmetic mean, where the data was encoded and entered into the computer. To determine the length of the triple questionnaire cells (minimum and upper limits), the range was calculated as follows: the largest value - the lowest value (3-1=2), divided by the number of cells of the questionnaire which obtained the corrected cell length $(2 / 3=0.67)$. This value was then added to the lowest value in the questionnaire or the beginning of the questionnaire, which determined the upper limit of this cell. Thus, cell length is as follows: 


\begin{tabular}{||cr|}
\hline The Egyptian Journal of Social Work (EJSW) https://ejsw.journals.ekb.eg/e \\
ISSN: $2356-9204$ & Vol 11, Issue.1, January2021 \\
\hline
\end{tabular}

\section{Table (1) questionnaire Levels:}

\begin{tabular}{|l|l|}
\hline If the average value of a phrase or dimension varies between 1 and 1.67 & Low level \\
\hline If the average value of a phrase or dimension varies between 1.67 and 2.35 & Mid-level \\
\hline If the average value of a phrase or dimension varies between 2.35 and 3.0 & High level \\
\hline
\end{tabular}

4- Statistical honesty: The study relied on ensuring the statistical validity of the questionnaire through the method of (retesting). The questionnaire was applied to a sample of (30) individuals, then reapplied to the same sample after fifteen days. The strength in reliability of the questionnaire phrases (alpha-Kronbach) was calculated using the SPSS program. The value of the Alpha parameter for the questionnaire phrases is $(0.722)$, which is an acceptable value. Thus, confirming the validity and consistency of the questionnaire paragraphs and the suitability of the questionnaire for application to the basic study sample.

\section{Sample:}

The study tools were applied through A comprehensive survey to female board members of civil society organizations specialized in the field of human rights and politically active, in addition to her work in the field of community development (Aelam alkhayr association for Community Development - Omar Ibn Al-Khattab association Charitable - alkhalil Ibrahim association Charitable) .The following table shows the study sample as follows:

\section{Table (2) illustrates the sample framework for the study}

\begin{tabular}{|l|l|l|l|}
\hline Sr & \multicolumn{1}{|c|}{ Name of organization } & \multicolumn{1}{|c|}{$\begin{array}{c}\text { Number of } \\
\text { female board } \\
\text { members }\end{array}$} & \multicolumn{1}{|c|}{$\begin{array}{c}\text { Number of service } \\
\text { beneficiaries }\end{array}$} \\
\hline 1 & $\begin{array}{l}\text { Aelam alkhayr association for Community } \\
\text { Development }\end{array}$ & 7 & 1455 \\
\hline 2 & $\begin{array}{l}\text { Omar Ibn Al-Khattab association } \\
\text { Charitable }\end{array}$ & 5 & 350 \\
\hline 3 & alkhalil Ibrahim association Charitable & 5 & 341 \\
\hline \multicolumn{2}{|l|}{ Total } & 17 & 2146 \\
\hline
\end{tabular}

Through the previous table, the study sample is determined as follows:

1- A comprehensive survey of female board members of organizations, totalling (17) individuals.

2- A random sample of the beneficiaries of the organizations' services within the local community reached (10\%) of the total, numbering (215) individuals. 
The Egyptian Journal of Social Work (EJSW) https://ejsw.journals.ekb.eg/e

- Reasons for choosing the study community:

1. To serve different geographical areas.

2. These organizations are more closely associated with the subject of the current study.

3. Responsible welcome these organizations to assist researchers.

\section{The determinants of the study:}

The results of this study are determined by the degree of reliability of the tool and its stability, as well as the objectivity of the respondents.

\section{Statistical Analysis Methods:}

Statistical processes were carried out using the SPSS.V. 20.0 software, specifically the statistical package for social sciences. The following statistical methods were applied:

1- Using the "Alpha Kronbach " coefficient, through which the discrimination coefficient for each question is calculated. The question with weak or negative discriminant coefficient is eliminated as the Alpha Cronbach coefficient expresses the degree of internal consistency of the questionnaire.

2- Calculating the range to determine the length of the questionnaire cells.

3- Calculating the arithmetic mean through the following equation: $=\mathrm{K}$ (Yes) x $3+\mathrm{K}$ (To a certain extent) x $2+\mathrm{K}(\mathrm{No}) \times 1 / \mathrm{N}$. The statements are sorted in a descending order, where statements with the highest arithmetic mean come first.

4- Determining the standard deviation through calculating the dispersion coefficient in the frequencies of the three responses for each statement. This helped sort the statements in cases where more than one statement had the same arithmetic mean.

\section{Study Limitations:}

1- Difficulty in reaching some women from the board of directors of human rights organizations. "The researchers were able to overcome this difficulty by making frequent field visits to female members of the Boards of Directors of human rights organizations working in the study community."

2- Confronting the procedural bureaucracy around obtaining data from human rights organizations operating in the study community. "The researchers were able to overcome this difficulty by obtaining permits from the Ministry of Social Solidarity, which is the authority overseeing civil organizations, and the researchers obtained a security mandate as well as the approval of organizations working in the study community." 


\begin{tabular}{||cr|}
\hline \multicolumn{2}{|c|}{ The Egyptian Journal of Social Work (EJSW) https://ejsw.journals.ekb.eg/e } \\
ISSN: $2356-9204$ & Vol 11, Issue.1, January2021 \\
\hline
\end{tabular}

The Results:

\section{Characteristics of the study community:}

Table (3) shows the distribution of women on the boards of directors of human rights organizations in the study community, as well as the beneficiaries of those organizations, according to social characteristics

\begin{tabular}{|c|c|c|c|c|c|c|c|}
\hline \multirow[t]{2}{*}{ Variables } & \multirow{2}{*}{\multicolumn{3}{|c|}{ Responses }} & \multicolumn{2}{|c|}{$\begin{array}{l}\text { Women board members of } \\
\text { organizations }(\mathrm{N}=17)\end{array}$} & \multicolumn{2}{|c|}{$\begin{array}{l}\text { The beneficiaries } \\
(\mathrm{N}=215)\end{array}$} \\
\hline & & & & $* \mathrm{~F}$ & $\%$ & $* \mathrm{~F}$ & $\%$ \\
\hline \multirow{3}{*}{ Gender } & 1 & \multicolumn{2}{|l|}{ Male } & & & 98 & 45.6 \\
\hline & 2 & \multicolumn{2}{|l|}{ Female } & 17 & 100 & 117 & 54.4 \\
\hline & \multicolumn{3}{|c|}{ Total } & 17 & $100 \%$ & 215 & $100 \%$ \\
\hline \multirow{5}{*}{ Marital status } & 1 & \multicolumn{2}{|l|}{ Single } & 1 & 5.9 & 12 & 5.6 \\
\hline & 2 & \multicolumn{2}{|l|}{ Married } & 11 & 64.7 & 81 & 37.7 \\
\hline & 3 & \multicolumn{2}{|l|}{ Divorced } & 3 & 17.6 & 44 & 20.5 \\
\hline & 4 & \multicolumn{2}{|l|}{ Widowed } & 2 & 11.8 & 78 & 36.3 \\
\hline & \multicolumn{3}{|c|}{ Total } & 17 & $100 \%$ & 215 & $100 \%$ \\
\hline & 1 & \multicolumn{2}{|l|}{ Illiterate } & 0 & 0.0 & 54 & 25.1 \\
\hline & 2 & \multicolumn{2}{|c|}{ Less than intermediate education } & 0 & 0.0 & 89 & 41.4 \\
\hline Fducational level & 3 & \multicolumn{2}{|c|}{ Intermediate education } & 2 & 11.8 & 54 & 25.1 \\
\hline Educational level & 4 & \multicolumn{2}{|l|}{ Higher education } & 12 & 70.6 & 15 & 7.0 \\
\hline & 5 & \multicolumn{2}{|l|}{ Postgraduate studies } & 3 & 17.6 & 1 & 0.5 \\
\hline & \multicolumn{3}{|c|}{ Total } & 17 & $100 \%$ & 215 & $100 \%$ \\
\hline & 1 & \multicolumn{2}{|l|}{ Unemployed } & 0 & 0.00 & 82 & 38.1 \\
\hline & 2 & \multicolumn{2}{|l|}{ Working in Public sector } & 2 & 11.8 & 29 & 13.5 \\
\hline & 3 & \multicolumn{2}{|l|}{ Working in private sector } & 5 & 29.4 & 61 & 28.4 \\
\hline Basic Work status & 4 & \multicolumn{2}{|l|}{ Self-employed } & 6 & 35.3 & 29 & 13.5 \\
\hline & 5 & \multicolumn{2}{|l|}{ Retired } & 4 & 23.5 & 14 & 6.5 \\
\hline & \multicolumn{3}{|c|}{ Total } & 17 & $100 \%$ & 215 & $100 \%$ \\
\hline \multirow{2}{*}{\multicolumn{3}{|c|}{$\begin{array}{l}\text { Years of experience of political participation in } \\
\text { human rights organizations }\end{array}$}} & $\mathrm{m}^{*}$ & 12.2 & & & \\
\hline & & & S.D* & 8.212 & & & \\
\hline \multirow{2}{*}{\multicolumn{3}{|c|}{$\begin{array}{l}\text { Years of benefiting from the services of the } \\
\text { organization in the local community }\end{array}$}} & $\mathrm{m}^{*}$ & & & 6.2 & \\
\hline & & & S.D* & & & 13.854 & \\
\hline \multirow{2}{*}{\multicolumn{3}{|c|}{ Average age }} & $\mathrm{m}^{*}$ & 43.1 & & 55.21 & \\
\hline & & & S.D* & 12.981 & & 16.21 & \\
\hline \multirow{2}{*}{ Average income } & & & $\mathrm{m}^{*}$ & 3012.2 & & 1400.54 & \\
\hline & & & S.D* & 4.21 & & 16.57 & \\
\hline
\end{tabular}

$\mathrm{F}=$ Frequency $\& * \mathrm{~m}=$ arithmetic mean $\& * \mathrm{~S} . \mathrm{D}=$ Standard Deviation) $\left(^{*}\right.$

The previous table regarding the characteristics of the study population, shows that the average age of women on the boards of directors in the sample is (43) years, with a dispersion factor of (12.981) indicating a large difference between their actual ages. The average age of beneficiaries of the services of the organization is (55) years, with a dispersion factor of (16.21), also indicating a large difference between their actual ages. The average monthly income of the women on the boards of directors in the sample is (3012) pounds, with a dispersion factor of (4.21), which points to an average convergence of income from the sample in this category.

The average monthly income for beneficiaries of the organizations' services was (1400) pounds, with a dispersion factor of (16.57), indicating a large difference between their actual monthly income. The majority of the 


\begin{tabular}{||c|c|}
\hline The Egyptian Journal of Social Work (EJSW) https://ejsw.journals.ekb.eg/e \\
ISSN: 2356-9204 & Vol 11, Issue.1, January2021 \\
\hline
\end{tabular}

beneficiaries of organizations' services are female with a percentage of (54.4\%), followed by males with $(45.6 \%)$. The marital status of women on the boards of directors in the sample is as follows; the majority were married with a percentage of (64.7\%), followed by divorced women (17.6\%). The marital status of individuals who benefit from the services of the organizations is as follows; the majority are married with a percentage of (37.7\%), followed by widows $(36.3 \%)$. The educational status of the women on the boards of directors in the sample is as follows; the majority reached higher education (70.6\%), followed by those with postgraduate studies (17.6\%). The educational status of individuals who benefit from the services of the organization in the local community is as follows; the majority have less than average education $(41.4 \%)$, followed by those who are illiterate and those with an average education (25.1\%). The employment status of the women on the boards of directors in the sample is as follows; most work for themselves (35.3\%), followed by those who work in the private sector $(29.4 \%)$. The employment status of individuals who benefit from the services of the organization in the local community is as follows; the majority do not work (38.1\%), followed by those who are in private work (28.4\%). The number of years of experience women have on the Boards of Directors in the sample averaged (12) years with a dispersion factor of (8.212). The large dispersion factor indicates that there are significant differences in the years of experience these women have on Boards of Directors in their organizations. The number of years of benefit individuals within the community have received from the organizations is (6) years with a dispersion factor of (13.854), which indicates the great difference between years of citizens 'use of organizations' services within the local community.

1- Determine the roles of political participation that women play in developing their local community, from the viewpoint of members of the local community.

Table (4) shows the distribution of the beneficiaries according to their perception of the roles of political participation that women play in developing the local community

\begin{tabular}{|c|c|c|c|c|c|c|c|c|c|}
\hline \multirow{3}{*}{$\begin{array}{l}\text { The roles of women in political } \\
\text { participation }\end{array}$} & \multicolumn{6}{|c|}{ The beneficiaries $(\mathrm{N}=215)$} & \multirow[b]{3}{*}{$\stackrel{*}{\Xi}$} & \multirow{3}{*}{ 葛 } & \multirow{3}{*}{ 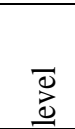 } \\
\hline & \multicolumn{2}{|l|}{ Yes } & \multicolumn{2}{|c|}{ To Some extent } & \multicolumn{2}{|l|}{ No } & & & \\
\hline & $* \mathrm{~F}$ & $\%$ & $* \mathrm{~F}$ & $\%$ & $* \mathrm{~F}$ & $\%$ & & & \\
\hline $\begin{array}{l}\text { Proper planning of all programs } \\
\text { and services provided to } \\
\text { individuals in the local } \\
\text { community. }\end{array}$ & 151 & 70.2 & 30 & 14.0 & 34 & 15.8 & 2.5 & 6.8 & $\begin{array}{l}\text { High } \\
\text { level }\end{array}$ \\
\hline $\begin{array}{l}\text { Estimation of the needs of local } \\
\text { community members and work } \\
\text { to satisfy them. }\end{array}$ & 108 & 50.2 & 74 & 34.4 & 33 & 15.3 & 2.3 & 3.7 & $\begin{array}{l}\text { Mid- } \\
\text { level }\end{array}$ \\
\hline Determination of the priority of & 167 & 77.7 & 30 & 14.0 & 18 & 8.4 & 2.7 & 8.2 & High \\
\hline
\end{tabular}




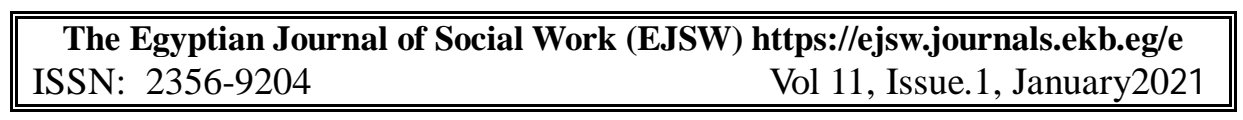

Table (5) shows that the level of significance is $(0.461)$. This value is greater than the value specified in the hypothesis which is $(0.05)$. Therefore, it can be noted that there are no statistically significant differences at the level of significance of $(0.05 \geq \alpha)$ with regard to the roles of political participation women play in the development of the local community, from the point of view of the members of society, according to gender. It also shows that there is a convergence between the mean for the male category (2.81) and the female category (2.84).

Table (6) shows the significance of the differences in the roles of political participation women play in the development of the local community, from the perspective of the members of society, according to the following variables (educational qualification, profession, age). Using one way a nova

\begin{tabular}{|c|c|c|c|c|c|c|}
\hline Variable & $\begin{array}{ll}\begin{array}{l}\text { Source } \\
\text { contrast }\end{array} & \text { of } \\
\end{array}$ & Sum of squares & d.f & $\begin{array}{l}\text { Average } \\
\text { squares }\end{array}$ & $\mathrm{f}$ & Sig \\
\hline \multirow{3}{*}{$\begin{array}{l}\text { Educational } \\
\text { qualification }\end{array}$} & $\begin{array}{l}\text { Between } \\
\text { Groups }\end{array}$ & 1.866 & 4 & 0.4665 & \multirow{3}{*}{0.420} & \multirow{3}{*}{0.111} \\
\hline & Within Groups & 232.003 & 209 & \multirow{2}{*}{1.1100} & & \\
\hline & total & 233.896 & 213 & & & \\
\hline \multirow{3}{*}{ Profession } & $\begin{array}{l}\text { Between } \\
\text { Groups }\end{array}$ & 0.395 & 4 & 0.09875 & \multirow{3}{*}{0.0906} & \multirow{3}{*}{0.453} \\
\hline & Within Groups & 227.731 & 209 & \multirow{2}{*}{1.0896} & & \\
\hline & total & 228.126 & 213 & & & \\
\hline \multirow{3}{*}{ Age } & $\begin{array}{l}\text { Between } \\
\text { Groups }\end{array}$ & 0.382 & 2 & 0.191 & \multirow{3}{*}{0.1737} & \multirow{3}{*}{0.465} \\
\hline & Within Groups & 231.998 & 211 & \multirow{2}{*}{1.0995} & & \\
\hline & total & 232.380 & 213 & & & \\
\hline
\end{tabular}

Table (6) shows, regarding the variable of educational qualification ${ }_{2}$ that the value of " $F$ " calculated is equal to (0.420) which is less than the value of "F" tabular at the "d.f" $(4,209)$, which equals (6.39.1.26) at the level of significance of $(0.05 \geq \alpha)$. There are statistically significant differences, at the level of significance of $(0.05 \geq \alpha)$, in the roles of political participation that women play in the development of the local community from the point of view of community members, according to the variable of educational qualification.

As for profession, the calculated value of $(\mathrm{F})$ was equal to (0.0906). It is less than the tabular value $(F)$ which equals $(6.39 .1 .26)$ at "d.f" $(4,209)$ at the level of significance of $(0.05 \geq \alpha)$. There is an absence of statistically significant differences at the level of significance of $(0.05 \geq \alpha)$ in the roles of political participation that women play in the development of the local community, from the point of view of community members ${ }_{2}$ according to the variable of profession.

As for age, the calculated value of $(\mathrm{F})$ was equal to $(0.1737)$. It is less than the tabular value $(F)$ which equals $(6.39 .1 .26)$ at "d.f" $(A, 211)$ at the level of significance of $(0.05 \geq \alpha)$. There are no statistically significant 


\section{The Egyptian Journal of Social Work (EJSW) https://ejsw.journals.ekb.eg/e}

ISSN: 2356-9204

Vol 11, Issue.1, January2021

differences at the level of significance of $(0.05 \geq \alpha)$ in the roles of political participation that women play in the development of the local community, from the point of view of community members, according to the age variable.

3- Reveal the nature of the differences in the roles of political participation women play in the development of their local community, as seen from the perspective of the woman herself, attributed to the following variables (educational qualification, profession, age, volunteer work in human rights organizations).

Table (7) shows the significance of the differences in the roles of political participation women play in the development of the local community from the point of view of the woman herself, according to the following variables (educational qualification, basic profession, age). Using one way a nova

\begin{tabular}{|c|c|c|c|c|c|c|}
\hline Variable & $\begin{array}{l}\text { Source } \\
\text { contrast }\end{array}$ & Sum of squares & d.f & $\begin{array}{l}\text { Average } \\
\text { squares }\end{array}$ & $\mathrm{f}$ & Sig \\
\hline \multirow{3}{*}{$\begin{array}{l}\text { Educational } \\
\text { qualification }\end{array}$} & $\begin{array}{l}\text { Between } \\
\text { Groups }\end{array}$ & 2.252 & 4 & 0.570 & \multirow{3}{*}{0.030} & \multirow{3}{*}{0.700} \\
\hline & Within Groups & 208.769 & 11 & \multirow{2}{*}{18.980} & & \\
\hline & total & 211.021 & 15 & & & \\
\hline \multirow{3}{*}{ Profession } & $\begin{array}{l}\text { Between } \\
\text { Groups }\end{array}$ & .728 & 4 & 0.190 & \multirow{3}{*}{0.010} & \multirow{3}{*}{0.200} \\
\hline & Within Groups & 206.581 & 11 & \multirow{2}{*}{18.780} & & \\
\hline & total & 207.309 & 15 & & & \\
\hline \multirow{3}{*}{ Age } & $\begin{array}{l}\text { Between } \\
\text { Groups }\end{array}$ & 0.450 & 2 & 0.225 & \multirow{3}{*}{0.020} & \multirow{3}{*}{0.734} \\
\hline & Within Groups & 209.680 & 13 & \multirow{2}{*}{16.130} & & \\
\hline & total & 210.13 & 15 & & & \\
\hline
\end{tabular}

Table (7) shows that, regarding the variable of educational qualification of female members of the boards of directors of organizations in the sample, the calculated value of " $F$ " is equal to $(0.030)$ which is less than the value of the schedule of " $F$ " which is equal to $(6.39,2.82)$ at "d.f" $(4,11)$ at the level of significance of (0.05). Thus, it is confirmed that there are no significant differences at the level of $(0.05 \geq \alpha)$ in the roles of political participation women play in the development of the local community, from the viewpoint of female members of the boards of directors of organizations, according to the variable of educational qualification.

As for the basic profession of female members of the boards of directors of organizations, the calculated "F" value is equal to $(0.010)$ and is less than the value of the "F" tabulation which is equal to $(6.39,2.82)$ at "d.f" $(4,11)$ at the level of significance of $(0.05)$. Thus, it is confirmed that there are no fundamental differences at the level of $(0.05 \geq \alpha)$ in the roles of political participation that women play in the development of the local community, from the viewpoint of female members of the boards of directors of organizations, according to the variable of the basic profession. 


\begin{tabular}{||cr||}
\hline \multicolumn{2}{|c|}{ The Egyptian Journal of Social Work (EJSW) https://ejsw.journals.ekb.eg/e } \\
ISSN: $2356-9204$ & Vol 11, Issue.1, January2021 \\
\hline
\end{tabular}

As for the age of female members of the boards of directors of organizations, the calculated value of " $F$ " is equal to (0.020), which is less than the value of scheduling "F", which is equal to $(9.55,2.85)$ at "d.f" $(2,13)$ at the level of significance_of (0.05). Therefore, it is confirmed that there are no significant differences at the level of $(0.05 \geq \alpha)$ in the roles of political participation that women play in the development of the local community, from the viewpoint of female members of the Boards of Directors of organizations, according to the age variable.

\section{4- Identify the obstacles that limit women's political participation in human rights organizations to achieve the development of local communities.}

Table (8) Distribution of female members of the boards of directors of organizations according to the obstacles that limit women's political participation through human rights organizations in achieving the development of local communities.

\begin{tabular}{|c|c|c|c|c|c|c|c|c|c|}
\hline \multirow{3}{*}{ Obstacle } & \multicolumn{6}{|c|}{ The beneficiaries $(\mathrm{N}=17)$} & \multirow{3}{*}{$\stackrel{*}{\Xi}$} & \multirow{3}{*}{$\stackrel{*}{\text { คे }}$} & \multirow{3}{*}{$\bar{d}$} \\
\hline & \multicolumn{2}{|c|}{ Yes } & \multicolumn{2}{|c|}{$\begin{array}{l}\text { To Some } \\
\text { extent }\end{array}$} & \multicolumn{2}{|l|}{ No } & & & \\
\hline & $* \mathrm{~F}$ & $\%$ & $* \mathrm{~F}$ & $\%$ & $* \mathrm{~F}$ & $\%$ & & & \\
\hline $\begin{array}{l}\text { The difficulty of participating } \\
\text { with the executive bodies in } \\
\text { setting plans for the development } \\
\text { of local communities. }\end{array}$ & 12 & 70.6 & 2 & 11.8 & 3 & 17.6 & 2.5 & 5.5 & $\begin{array}{l}\text { High } \\
\text { level }\end{array}$ \\
\hline $\begin{array}{l}\text { The difficulty of participating } \\
\text { with executive bodies in making } \\
\text { decisions related to development. }\end{array}$ & 11 & 64.7 & 1 & 5.9 & 4 & 23.5 & 2.3 & 5.1 & $\begin{array}{l}\text { Mid- } \\
\text { level }\end{array}$ \\
\hline $\begin{array}{l}\text { Lack of communication channels } \\
\text { between women, members of } \\
\text { councils of local organizations } \\
\text { and leaderships within the } \\
\text { community. }\end{array}$ & 13 & 76.5 & 3 & 17.6 & 1 & 5.9 & 2.7 & 6.4 & $\begin{array}{l}\text { High } \\
\text { level }\end{array}$ \\
\hline $\begin{array}{l}\text { Difficulty exchanging } \\
\text { information and experiences } \\
\text { between organizations within the } \\
\text { community. }\end{array}$ & 9 & 52.9 & 2 & 11.8 & 6 & 35.3 & 2.2 & 3.5 & $\begin{array}{l}\text { Mid- } \\
\text { level }\end{array}$ \\
\hline $\begin{array}{l}\text { Women refrain from political } \\
\text { participation. }\end{array}$ & 14 & 82.4 & 3 & 17.6 & 0 & 0.0 & 2.8 & 7.3 & $\begin{array}{l}\text { High } \\
\text { level }\end{array}$ \\
\hline The general value of the variable & 59 & 70.2 & 11 & 13.1 & 14 & 16.7 & 2.5 & Hig & level \\
\hline
\end{tabular}

$\mathrm{F}=$ Frequency $\& * \mathrm{~m}=$ arithmetic mean $\& * \mathrm{~S} . \mathrm{D}=$ Standard Deviation)

Table (8) shows that the obstacles facing the political participation of women in the development of their society are at a high level, with an arithmetic average of (2.5). The most significant obstacles were the reluctance of women to participate in politics, with an average of (2.8), followed by the lack of communication channels between female members of the councils of local organizations and leaders within the community, with an arithmetic 


\begin{tabular}{||c|c|}
\hline The Egyptian Journal of Social Work (EJSW) https://ejsw.journals.ekb.eg/e \\
ISSN: 2356-9204 & Vol 11, Issue.1, January2021 \\
\hline
\end{tabular}

average of (2.7), followed by the difficulty of participating with the executive agencies in developing plans for the development of local communities, with an average arithmetic of (2.5), then the difficulty of participating with the executive agencies in making decisions related to development, with an average score of (2.3), and lastly, the difficulty of exchanging information and experiences between organizations within the community with an average of (2.2).

\section{5- Proposals to support women's political participation in human rights organizations to achieve societal development.}

Table (9) Distribution of women amongst members of the Boards of Directors of the organizations according to suggestions supporting women's political participation in achieving the development of local communities.

\begin{tabular}{|c|c|c|c|c|c|c|c|c|c|}
\hline \multirow{3}{*}{ Proposals } & \multicolumn{6}{|c|}{ The beneficiaries $(\mathrm{N}=17)$} & \multirow{3}{*}{$\stackrel{*}{\Xi}$} & \multirow{3}{*}{$\stackrel{*}{\stackrel{*}{\rho}}$} & \multirow{3}{*}{$\overrightarrow{\vec{d}}$} \\
\hline & \multicolumn{2}{|c|}{ Yes } & \multicolumn{2}{|c|}{$\begin{array}{l}\text { To Some } \\
\text { extent }\end{array}$} & \multicolumn{2}{|l|}{ No } & & & \\
\hline & $* \mathrm{~F}$ & $\%$ & $* \mathrm{~F}$ & $\%$ & $* \mathrm{~F}$ & $\%$ & & & \\
\hline $\begin{array}{l}\text { Increasing cooperation between } \\
\text { human rights organizations and } \\
\text { the executive bodies to achieve } \\
\text { local development. }\end{array}$ & 11 & 64.7 & 4 & 23.5 & 2 & 11.8 & 2.5 & 4.7 & $\begin{array}{l}\text { High } \\
\text { level }\end{array}$ \\
\hline $\begin{array}{l}\text { The exchange of development } \\
\text { plans with the concerned agencies } \\
\text { within the community. }\end{array}$ & 9 & 52.9 & 5 & 29.4 & 3 & 17.6 & 2.4 & 3.0 & $\begin{array}{l}\text { Mid- } \\
\text { level }\end{array}$ \\
\hline $\begin{array}{l}\text { Create incentives to encourage } \\
\text { women to participate in politics to } \\
\text { achieve the development of local } \\
\text { communities. }\end{array}$ & 15 & 88.2 & 1 & 5.9 & 1 & 5.9 & 2.8 & 8.0 & $\begin{array}{l}\text { High } \\
\text { level }\end{array}$ \\
\hline $\begin{array}{l}\text { Encouraging } \text { women to } \\
\text { participate in politics by } \\
\text { integrating them into decision- } \\
\text { making circles. }\end{array}$ & 16 & 94.1 & 1 & 5.9 & 0 & 0.0 & 2.9 & 8.9 & $\begin{array}{l}\text { Mid- } \\
\text { level }\end{array}$ \\
\hline $\begin{array}{l}\text { Opening channels } r \text { of } \\
\text { communication with women } \\
\text { within society to motivate them to } \\
\text { participate in politics. }\end{array}$ & 13 & 76.5 & 2 & 11.8 & 2 & 11.8 & 2.6 & 6.3 & $\begin{array}{l}\text { High } \\
\text { level }\end{array}$ \\
\hline
\end{tabular}

$(\mathrm{F}=$ Frequency $\& * \mathrm{~m}=$ arithmetic mean $\& * \mathrm{~S} . \mathrm{D}=$ Standard Deviation $)$

Table (9) shows that the most important proposals to support the political participation of women in the development of their society were to encourage women to participate in politics by integrating them into decision-making circles, with an arithmetic average of (2.9). This was followed by the development of incentives to encourage women to participate in the political achievement of the development of local communities, with an arithmetic average of (2.8), then, the opening of communication channels with women 
within the community to motivate them to participate in politics, with an average of (2.6), followed by increased cooperation between human rights organizations and executive bodies to achieve local development, with an average score of (2.5), and lastly, the exchange of development plans with relevant agencies within the community, with an average of (2.4).

Discussion:

Considering the first aim: "Define the roles of political participation that women play in the development of their local community as seen from the perspective of members of the community" the results of the study confirm that the most important roles are: Participation in policy-making with the authorities responsible for community development, and determining the priority of services provided to citizens within the community. This is consistent with the study of (Jane \& Ganigera, 2013) which explored strategies to enhance the status of women and political participation in local government, and the study of (Ghaplanyan \& Melikyan, 2015) regarding the strengthening of the political involvement of women.

In light of the second and third goals of the study: "Reveal the nature of differences in the roles of political participation that women play in the development of their local community, as seen from the perspective of members of society and the woman herself, which are attributed to the following variables (gender, educational qualification, profession, age)" the results of the study show that there are no statistically significant differences, at the level of $(0.05 \geq \alpha)$, between the roles of political participation that women play in the development of their local community, as seen from the perspective of members of society and the woman herself, which are attributed to the following variables (gender, educational qualification, profession, age).

In light of the fourth study goal. "Identify the obstacles that limit women's political participation, through human rights organizations, in achieving the development of local communities" the results of the study confirmed that the most significant obstacles were: the reluctance of women to participate in politics, followed by the lack of communication channels between female members of the councils of local organizations and leaders within the community. This is consistent with the study of (Agbalajobi, 2010) which aimed to identify the problems facing women in their pursuit of political participation, and the study of (Kassa: 2015) which indicated the challenges and opportunities for women's political participation. 


\section{The Egyptian Journal of Social Work (EJSW) https://ejsw.journals.ekb.eg/e}

In light of the fifth and special study goal: "Produce proposals to support women's political participation, through human rights organizations, in achieving community development" the results of the study confirmed that the most important proposals were: support the political participation of women in the development of their society by encouraging them to participate in politics by integrating them into decision-making circles, followed by the development of incentives to encourage women to participate in the political development of local communities. This is consistent with the study of (Ghaplanyan \& Melikyan, 2015) about strengthening the political participation of women, and the study of (Bradshaw, S., Castellino, J. and Dipo, B.:2013) regarding the importance of the role of women in the development process.

\section{Study recommendations:}

1- Encourage women to participate in politics by integrating them into decision-making circles.

2- Create incentives to encourage women to participate in politics to achieve the development of local communities.

3- Open channels of communication with women in society to motivate them to participate in politics.

\section{References:}

Al-Srouji, T. M. (2012). Social Development from Modernity to Globalization, Alexandria, Modern University Office.

Pelak, C.F., Taylor,_V., Whittier, N. (1999). Gender Movements, in "J. Salzten Chafetz (ed.) Hand book of the Sociology of Genre". New York, Plenum.

Miles, A. (1996). Integrative feminisms" building global visions, 1960s-1990s", New York, rout ledge.

Maysoon, D. (2006). The effect of the training program in the centers of the Jordanian Hashemite Fund for Human Development on the empowerment of Jordanian women, Master Thesis, University of Jordan, Amman, Jordan.

Security Council (2000). resolution 1325, calls for broad participation of women in peacebuilding post-conflict reconstruction, unanimously adopting United Nations. 31 October.

Chowdhury ،Anwarul (2010). Women Are Essential for Sustainable Peace, Universal Peace Federation, Bern, Switzerland.

Ross, Marry (1995). Community Organization and Practice, M.T. Harper and Brash, ESE.

Agbalajobi._D. T (2010). Women's participation and the political process in Nigeria: Problems and prospects, African Journal of Political Science and International Relations Vol. 4(2), pp. 075-082, February 2010 ISSN 1996-0832 .Academic Journals.

Kassa, S. (2015). Challenges and Opportunities of Women Political Participation in Ethiopia, Journal of Global Economics. V.3:4.

Ghaplanyan. I \& Melikyan. A (2015). Strengthening Women's Political Participation in the Republic of Armenia: Existing Efforts, Challenges and Opportunities. Report by United States Agency for International Development (USAID).

Jane, A. \& Ganigera, S. (2013). Strategies for strengthening women's position and political participation in local self-government: an exploratory study. Golden Research Thoughts, Volume 2, Issue. 11-May. 
Muhammed M. H (2017). Women`s Political Participation in Local Government in Ethiopia: The Case of Two Districts in Amhara Regional State. Master's Thesis in Public Administration. University of Bergen, department of administration and organization theory.

Bradshaw, S., Castellino, J. and Dipo, B.,_(2013)._Women's role in development: Overcoming the constraints, Back Paper on the Post -2015 development Agenda, 20 May 2013, Sustainable Development Solutions Network, A Global Initiative for The United Nations.

Economic and Social Commission for Western ASIA (ESCWA) (2012). Addressing Barriers to Women's Economic Participation in the Arab Region, E/ ESCWA/ ECW/2012/1,2 October United Nation, New York.

Al-Darir, M.\& Zakaria, K. (1997). Population and development, Damascus University, United Nations, Damascus, Syria.

Kandy, Karoline (2017). Are Women More Risk Averse?, Economic Inquiry 620.

Saeed, Nader (1998). Palestinian Women and Development, Development Studies Program, Ministry of Planning and International Cooperation, Series of Planning for Development, No.3.

Al-Dawwa, M. E. Suleiman (2018). Bahraini women's political participation challenges and aspirations, 1st edition, Bahrain, Bahrain Institute for Political Development.

Bystydzienski, Jill._M. (1991). Women Transforming politics, World Wide, Strategic for Empowerment, Indiana University Press.

El-Gohary, Abd el-Hady (1998). Sociology Dictionary, Alexandria, Modern University Office

Al-Sukari, A. S. (2000). Dictionary of Social Work and Social Services, Alexandria, Dar AlMaarefa Al-Aljamieia, p.247.

Dunham, Arthur (1970). The New Community Organization, New York, Thomas\& Crowell.

Abrai, Julie. S. \& Rosenthal, Beth B (2008). Interdisciplinary and inter Organization Collaboration, In encyclopedia of Social Work 19th Edition NASW. N.Y.

Ahmed, Rashad (1999). Models and skills of community organization in the social service "an integrative approach", Alexandria, Modern University Office.

Zahran, Hamdiya (2000). The role of Egyptian women in production within the framework of comprehensive national development, National Population Council, Cairo. 